\title{
The Representation of Military Troops in Pingcheng Tombs and the Private Household Institution of Buqu in Practice
}

\author{
Chin-Yin TSENG
}

\begin{abstract}
In Northern Wei tombs of the Pingcheng period (398-494 CE), we notice a recurrence of the depiction of armed men in both mural paintings and tomb figurines, not in combat but positioned in formation. Consisting of infantry soldiers alongside light and heavy cavalry accompanied by flag bearers, such a military scene presents itself as a point of interest amidst the rest of the funerary setting. Is this supposed to be an indication that the tomb occupant had indeed commanded such an impressive set of troops in life? Or had the families commissioned this theme as part of the tomb repertoire simply in hopes of providing protection over the deceased in their life after death? If we set the examination of this type of image against textual history, the household institution of buqu retainers that began as early as the Xin ("New") Dynasty (9-23 CE) and was codified in the Tang Dynasty (618-907 CE), serving as private retainer corps of armed men to powerful families, appears to be the type of social institution reified in the archaeological materials mentioned above. The large-scale appearance of these military troops inside Pingcheng period tombs might even suggest that with the "tribal policy" in place, the Han Chinese practice of keeping buqu retainers became a convenient method for the Tuoba to manage recently conquered tribal confederations, shifting clan loyalty based on bloodline to household loyalty based on the buqu institution, one with a long social tradition in Chinese history.
\end{abstract}

Keywords: Northern Wei, Pingcheng, buqu, armed retainers, tribal policy

\section{Prikaz vojaških enot v grobnicah iz mesta Pingcheng in institucija privatne družinske vojske buqu v praksi}

\section{Izvleček}

V grobnicah dinastije Severni Wei iz časa t. i. obdobja Pingcheng (398-494 n. št.) opazimo ponavljajoči se motiv upodobitve oboroženih mož na stenskih poslikavah in nagrobnih figurah, ki niso upodobljeni sredi boja, temveč v formaciji. Ti vojaški prizori, ki prikazujejo pehoto skupaj z lahko in težko konjenico ob spremljavi zastavonoš, se

Chin-Yin TSENG, “Digital Dunhuang” Reasearch Fellow,

Dunhuang Academy, Gansu Province, China.

Email address: chinyin.tseng[at]gmail.com

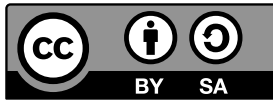


kažejo kot osrednji motiv v sklopu upodobitve pogrebnega obreda. Ali to nakazuje, da je pokopani za časa življenja zares poveljeval tako impresivni množici vojakov? Ali so nemara družine naročile tak motiv kot del grobniškega repertoarja preprosto $\mathrm{v}$ upanju, da bi zaščitile pokojnega $v$ njegovem posmrtnem življenju? Če se lotimo proučevanja te vrste podob v luči tekstovnega zgodovinskega gradiva, lahko vidimo, da je bila institucija družinskih vojaških podanikov buqu, ki se je začela že vsaj za časa dinastije Xin (9-23 n. št.), nato kodificirana za časa dinastije Tang (618-907 n. št.) in je služila kot sistem privatnih enot oboroženih podanikov mogočnih družin, vrsta družbene institucije, ki je potrjena v prej omenjenem arheološkem gradivu. Obsežne upodobitve teh vojaških sil v grobnicah iz obdobja Pingcheng nemara celo nakazujejo, da je v okviru izvajanja t. i. plemenske politike praksa vzdrževanja podanikov buqu hanskih Kitajcev postala priročna metoda za ljudstvo Tuoba pri upravljanju nedavno osvojenih plemenskih konfederacij, s premikom klanske zvestobe, temelječe na krvi, na zvestobo družini, temelječi na instituciji buqu z dolgo družbeno tradicijo v kitajski zgodovini.

Ključne besede: Severni Wei, Pingcheng, buqu, oboroženi podaniki, plemenska politika

\section{Introduction}

A visual motif found in Northern Wei Pingcheng period tombs (398-494 CE) is the depiction of armoured and armed men positioned in formation as a part of the application of the funerary repertoire. This visual motif can be identified in the tombs of Shaling 沙嶺 M7 (Fig. 1) (Datong shi kaogu yanjiusuo 2006), Yanbei shiyuan 雁北師院 M5 (Fig. 2) (Datong shi kaogu yanjiusuo 2008), and Sima Jinlong 司馬金龍 (Fig. 3) (Shanxi sheng Datong shi bowuguan et al. 1972), taking form as either a mural painting or clay figurine set.

Portraying an entourage of armed men as a part of the visual repertoire surrounding the tomb space of the deceased has had a long tradition in Chinese funerary art. This type of portrayal produced a variety of thematic subjects that emerged as early as the Han Dynasty, on carved pictorial stones and moulded pictorial bricks, including the “outing scene” (chuxing tu 出行圖), “battle scene” (zhanzheng tu 戰 爭圖), and “hunting scene” (shoulie tu 狩獵圖). In the Han funerary repertoire, we see motifs of the "outing scene" with ox cart and saddled horse, "battle scene" with armed men in combat, and "hunting scene" with men on horseback equipped with bow and arrow galloping in the hills. However, in the Pingcheng tombs, what we see is a new type of representation for the depiction of armed men, exhibiting the funerary military set in a rather extraordinary manner.

While traditional funerary thematic subjects to be found as early as the Han Dynasty continued strongly into the Northern Wei Pingcheng tombs as popular motifs, what we see here on the Shaling north wall does not quite conform to any of the above thematic renditions. These armoured and armed assemblages 
found within the Pingcheng tombs are always positioned in formation, but not engaged in combat. They consist of the full range of infantry soldiers, light and heavy cavalry, accompanied by flag bearers as well as other members of the procession to produce the full effect of pomp and circumstance. One might even say that these troops, in the way they were represented, either in painting or in sculpture, appear to be more ceremonial than martial. Most importantly, it is interesting to note that such a type of military set does not necessarily correspond with the tomb occupant's position in court as one who may have commanded such an impressive army.

The fact remains that Northern Wei Pingcheng tombs do not contain any textual evidence to suggest precisely what these visual motifs intend to represent. One could choose to interpret the mural subject on the Shaling north wall as a grandiose rendition of the traditional "outing scene". Nonetheless, this paper aims at placing the appearance of this mural image together with the intriguing sets of clay figurines found in the tombs of Sima Jinlong and Song Shaozu 宋紹祖 (Yanbei shiyuan M5) as indicative of a social phenomenon that had re-emerged to be picked up in the Pingcheng period.

Rather than interpreting the military entourage as representing the tomb occupants' official capacity in court, it could be more enlightening if we are to treat it as an icon of the scale of household befitting the deceased in their lifetime. This paper explores how this specific representation of armoured and armed men in formation during this time period could very well represent a social institution that was part of the practice of the Nanbei chao (420-589 CE) - private household bound retainers, also known as buqu 部曲.

\section{Tomb Assemblages}

Within the Pingcheng period tombs, such a set of military assemblage is most distinctly observed in Shaling M7 (dated to $435 \mathrm{CE}$, mural on north wall), Yanbei shiyuan M5 (dated to 477, clay figurines), and the tomb of Sima Jinlong (dated to 484, clay figurines). Appearing either as painted images or clay figurines, this specific visual motif exists in different variations while having shared characteristic features, particularly in the types of military categories included in the set, as well as in the representation of their respective headgear and apparel down to the finer details. In fact, the two sets of clay figurines appear very much as if the troops had marched right out of the north wall of Shaling M7, transforming a two-dimensional mural image into sets of vivid three-dimensional figurines. 


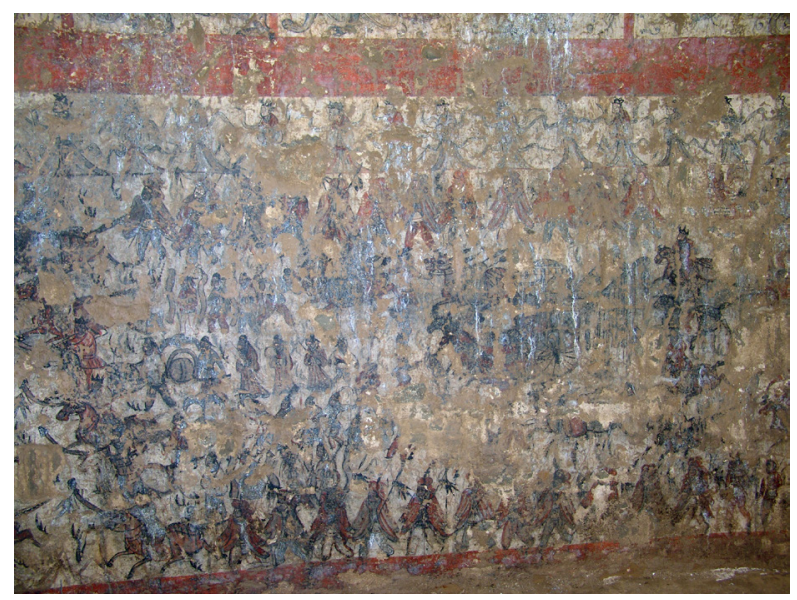

Figure 1: Mural on the north wall of Shaling M7, Shanxi (After Datong shi kaogu yanjiusuo 2006, 19).

Shaling M7, identified by a piece of inscribed lacquer fragment, has been attributed to the mother of a Xianbei general by the clan name of Poduoluo, buried in 435 $\mathrm{CE}$. The aforementioned type of military entourage is depicted across the north wall of Shaling M7, which takes up approximately $6.43 \mathrm{~m}^{2}$ of wall space. At first sight, the mural appears to have merged what would have been either a hunting or military combat scene on a Han stone relief or on a Wei-Jin brick mural into a military procession. The military entourage depicted on the north wall consists of flag bearers, foot soldiers with long spears and bows and arrows, as well as light and heavy cavalry. The military group is enhanced with marching musicians and acrobatic performers, giving the scene an air of pomp and circumstance.

At the centre of this composition, led up front by scouts on horseback, is a canopied horse-drawn carriage. It is because of this horse-drawn carriage that the excavation report continues to refer to this visual representation as a "carriage and horse outing scene" (chema chuxing tu 車馬出行圖), and other authors who wrote about this mural image also classified it either as "carriage and horse guards of honour outing scene" (chema yizhang chuxing tu 車馬儀仗出行圖) (Tao 2013), “outing scene" (chuxing tu 出行圖) (Zhang 2017), or “imperial procession scene” (lubu tu 图簿圖) (Wei 2017). Clearly, all these thematic descriptions focus on the horse-drawn carriage as the central element of a processional outing, and these are simply different terms for describing, at different levels of ceremonial complexity and the scale of entourage involved, an activity that the deceased would have engaged in, in everyday life.

The head of a male figure appears just above the carriage under the canopy, depicted on the north wall of Shaling M7, which suggests that he takes up the central 
position within this entourage. Seeing that the tomb occupant has been identified as Lady Poduoluo, whose son was a Northern Wei general, it is very easy to make the leap in logic that this military entourage was depicted to represent the status of her son in the Northern Wei court, an outing scene together with the army he commanded in an official capacity. While this may very well be a valid interpretation, one question remains: why depict an activity that was not necessarily a central aspect of Lady Poduoluo's life, but that of her son? Or, perhaps this motif deserves an alternative interpretation, one that stems from the everyday activities within the household of the deceased, rather than as a marker of the official capacity once held by the deceased.

It thus may be more beneficial for the purpose of this paper if we shift our emphasis from necessarily labelling the type of activity depicted to exploring the nature of the relationship between these armed men and the tomb occupant. The sheer number of armed and armoured men, including those in heavy armour, marching in a disciplined manner, makes this image a clear deviation from all existing conventional motifs involving military men as an entourage for the tomb occupant. The question remains: who are these people, as armed troops, accompanying the tomb occupant into eternity?

The role of such a set of armed troops in a Pingcheng funerary setting is even more intriguing when represented by the more than hundred pieces of clay figurines found in the tombs of Song Shaozu (Yanbei shiyuan M5) and Sima Jinlong. As tomb assemblages reflect actual practices of daily life, by having these figurines of armed troops included in their life after death, what would the tomb occupant, or those making this decision, have intended for the figurines to duplicate from their life above ground?

Yanbei shiyuan M5 is attributed to the Regional Inspector of Youzhou 幽州 who was also the Duke of Dunhuang, Song Shaozu, and his wife, dated to 477. It contains a set of 113 pieces of clay figurines, of which the large military assemblage makes up a great majority of the entire set. Consisting of light armoured and heavy armoured cavalry as well as foot soldiers and flag bearers, these warriors appear to have stepped out of the mural painting across the north wall of Shaling M7. A common feature shared by the mural and the clay figurines is the attention to detail in the representation of the individuals involved, especially when it comes to the variety of headgear and apparel worn by each soldier, depending on the role they perform in the military assemblage.

Clay figurines and models, just like pictorial stones, were applied in Chinese burials as an aspect of the funerary repertoire that accompanied the tomb occupants. Figurine attendants, models of granaries, as well as everyday objects, all made of 
clay, were to be found in tombs as early as the Warring States period (476-221 $\mathrm{BCE}$ ). By the Northern Wei period, while the notion of clay figurines is nothing out of the ordinary as a category of funerary goods, it is the prominence given to the military roles in the figurine sets of Song Shaozu and Sima Jinlong that makes them intriguing. Represented either on horseback or on foot, these warrior figurines in full armour remind us of the famous Terracotta Warriors of the First Emperor Qin Shihuang 秦始皇 (259-210 BCE) at Lishan 驪山, and those of the Han Emperor Jingdi 景帝 (188-141 BCE) at Yangling 陽陵, bearing close resemblance to the former in the intricacy with which the minute details of the soldiers' apparel and armour were shaped out of clay, and to the latter in their diminutive stature.

This knowledge presents us with an oddity. In the Han Dynasty, from which only a handful of princely tombs have been discovered that contain miniature terracotta warriors, Song Shaozu's warrior figurines appear to be a transgression upon sumptuary protocol, a diversion from contemporary funerary practice. Despite the prominent social status of the Dunhuang Song clan, and the fact that many of its high members held military appointments either as commanders or strategists (Shi 1991), the fact remains that the display of such a troop of miniature warrior figurines was not a common funerary practice for military men in the period leading up to this time, as demonstrated by the lack of miniature figurine troops in Hexi tombs of the Wei-Jin period. Furthermore, despite the prominence of the Song family in the Dunhuang locality, Song Shaozu remains a member of the Northern Wei court who is not even mentioned in the Book of Wei (Weishu 魏書). All of these are reasons to suggest that Song Shaozu's clay figurine troops did not necessarily exist as a marker of an imperial commander of such a troop.

Surprisingly, or perhaps not so, Yanbei shiyuan M5 is not the only example of such a tomb from the Pingcheng period. Another one dated a few years later $(484 \mathrm{CE})$, attributed to Sima Jinlong, also contains a similar set of miniature clay warrior figurines (122 on foot and 88 mounted on horse). Sima Jinlong was the son of Sima Chuzhi 司馬楚之, a side-line descendant of the royal Sima clan of the Eastern Jin who sought refuge in the North to escape from Liu Song's persecution of the Jin Sima clan, and married the Henei Princess of the Tuoba Northern Wei.

Like his father, Sima Jinlong served in the Northern Wei court, yet unlike his father, Sima Jinlong was never a true military man. Earlier in his career, he served as the commander of the Yunzhong garrison (yunzhong zhenjiang 雲中 鎮將), and was in fact the local governor of the Yunzhong garrison, a mid-level civil-military administrator in nature. At the highest point of his official career, 


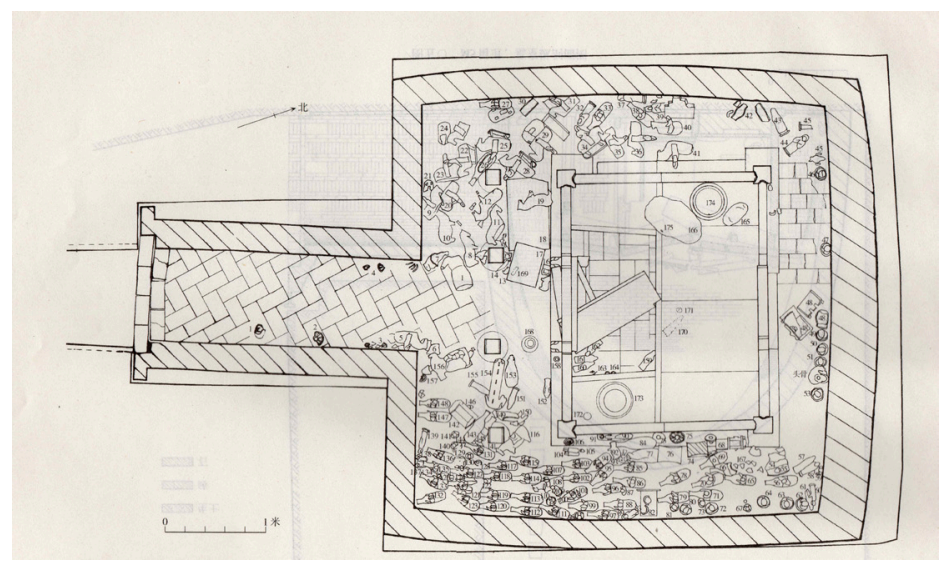

Figure 2: Section view of Yanbei shiyuan M5 tomb chamber with indications of the clay figurine distribution, Shanxi (After Datong shi kaogu yanjiusuo 2008, 74).

Sima Jinlong was appointed Palace Attendant (shizhong 侍中) and conferred on a brevet rank of Grand General for Pacifying the West (zhenxi dajiangjün 鎮 西大將軍). As such, it would be inappropriate for a civil official such as Sima Jinlong himself to expect to command and/or to be protected by Northern Wei military troops for all eternity. To attribute the appearance of these military figurines to Sima Jinlong's father, who had served his career as a military man, is also problematic, as such an official command of Northern Wei troops was certainly not hereditary, even less conceivable as part of the sumptuary protocol for funerary rites.

Even so, a discussion of whether or not Song Shaozu or Sima Jinlong's official career merited the application of such a funerary setting is a distraction from the issue at hand. To have what only appeared in the highest-ranking imperial tombs of the Qin and Han Dynasties, unaccounted for in the Wei-Jin tombs, yet found in two Pingcheng tombs, is clearly a funerary phenomenon worth discussing as a possible reflection of Northern Wei socio-historical changes. The particularity of the armed clay figurines in the Northern Wei Pingcheng period tombs is most significant when we observe the lack of these figurines even in later Luoyang period tombs attributed to Northern Wei Emperor Xuanwu 宣武 (Yuan Ke 元 恪, 499-515) (Zhongguo shehui kexueyuan kaogu yanjiusuo et al. 1994) and the last emperor of the Northern Wei, Emperor Jiemin 節閔帝 (Yuan Gong 元恭, r. 531-532) (Liu 2014).

Though both tombs had been disturbed by tomb robbers, with no textual evidence remaining, the scale and layout of the tomb burials all suggest that the 
tomb occupants were related to the Imperial Court. Nonetheless, what is left of the clay figurine sets suggest that heavy and light cavalry may have not been included in the original repertoire. In what appears to be Emperor Jiemin's burial at Beimang Mountain 北邙山, his set of clay figurines consist of civil bureaucrats, and what appears to be guards of honour, horses and camels; unfortunately, only the heads of three civil bureaucrats remain intact, so not much more information could be gathered from the rest. As for the remains of the clay figurines in what scholars have attributed to be Emperor Xuanwu's Jing Mausoleum 北魏宣武帝景陵, also without textual evidence, only fragments of animal models are found, too fragmented that one could only make out the shapes of hogs and dogs. The lack of any sign of a fighting force represented in these two imperial burials makes their appearance in the tombs of Song Shaozu and Sima Jinlong even more intriguing.

Recalling Erwin Panofsky's dualistic perception of funerary art as reflecting prospective and retrospective concerns $(1964,10)$, the appearance of armoured and armed men could easily suggest to the viewer that they were intended for the protection of the deceased, either in this life or the next. However, if there is no indication that the tomb occupants had necessarily commanded such an impressive military force in their lifetime, and considering that figurines of guardian beasts and guardian warriors already exist for the actual protection of the cave space, what would such a military assemblage intend to represent in the life of a Northern Wei Pingcheng household? This leaves us to consider whether such an armed figurine assemblage could have other social interpretations besides that indicative of an eternal army commanded by a sovereign or royal prince.

This very question guides the following enquiry, as this paper sets forth to examine the historical context for such a visual motif would exist in the first place as a separate category apart from other large-scale narratives of armed and armoured men in action. When we set these archaeological materials against textual history, the social institution of buqu retainers serving as private retainer corps of armed men to powerful families, might be just what the visual motif intends to re-enact.

\section{Buqu Retainers}

The original meaning of buqu, as it first appeared in historical texts, referred to an official institutional method of organising military troops into regular units that started in the Western Han (202 BCE-9 CE) (Graff 2002, 38-39; Lewis 2009, 58). Going back to the dynastic histories, in the Book of Later Han (Hou Hanshu 後漢書), the chapter on “Hundred Officials," it is said that: 
其領軍皆有部曲。大將軍營五部, 部校尉一人, 比二千石。軍司 馬一人, 比千石。部下有曲, 曲有軍候一人, 比六百石。曲下有 屯，屯長一人，比二百石。(Fan 1965, 3564)

[As for generals,] each army they lead has $b u$ and $q u$. For the Great General ['s army], each $y$ ing has five $b u$, and each $b u$ has one man as xiaowei, [an official] ranking at two thousand piculs, and one man as junsima, [an official] ranking at one thousand piculs. Under each $b u$ there is a $q u$, and each qu has one man as junhou, [an official] ranking at six hundred piculs. Under each $q u$ there is a tun, and each tun has one man as tunzhang, [an official] ranking at two hundred piculs. ${ }^{1}$

By the time of the Eastern Han, the meaning of buqu as a designation for an official military institution took a turn (Ke 1963), mostly as a result of the social turbulence in the interim period between the Western and Eastern Han, known as the Xin ("New") Dynasty (9-23 CE), a short-lived dynasty established by Wang Mang. During this period, amidst chaos and disorder, regional strongmen and landowners emerged to gain social and political influence. In order to protect their own assets, these powerful landowning families took up the practice of arming their clansmen, retainers, followers, and dependents of the household. What may have begun as a measure for estate protection in times of disorder, eventually turned into the militarisation and institutionalisation of private fighting forces at the command of powerful households.

As early as the Xin Dynasty, these militarised retainers of private households, who would have normally conducted work on estate production in times of peace, came to be known as buqu. Though in the following Eastern Han period (25-220 CE) the practice was more discreet in nature and had not become an actual form of household institution until the end of the Eastern Han with the Yellow Turban Rebellion and the ensuing fragmentation of society caused by the warlords. Peasants whose lives were upended by constant warfare sought refuge in armed estates. In turn, they became new additions to the armed forces of these households, and the growing number required these households to adopt the practice of militarising retainers in order to institutionalise their large following.

It is important to point out that buqu, though of a private nature, should not be used interchangeably with the notion of "private military soldiers" (sibing 私 兵), who were professional soldiers loyal to an individual instead of the state. I would argue against the statement that in the Eastern Han buqu were soldiers

1 Translations of primary texts into English are all done by the author. 
who developed close ties with the generals and landed magnates, making them "private troops" (Lewis 2009, 58). Buqu were by no means professional soldiers. The notion of buqu focuses on a type of medieval social identity, that of being one of the "unworthy populations" (jianmin 賤民). Combat was just one of the functions assumed by buqu on the estates. In peaceful times, buqu were never disengaged from their primary duty as production forces on an estate, and only served as an armed force during particular periods of disorder.

In the post-Han, Wei-Jin Nanbei period (220-589 CE), as a result of warfare and social instability, the main source of recruitment for buqu originally relied on clansmen at its core, which later extended outward to other types of retainers, including pupils and followers of these families, public recruits, and other servile dependents bestowed by the emperor (Wang 2004). Amidst the turmoil of $311 \mathrm{CE}$ in Luoyang, the Jin statesman $\mathrm{Zu}$ Ti led his clansmen to seek refuge in Huaisi (present day Xuzhou, Jiangsu province), only to later return north with his household buqu and new recruits to take back Yuzhou (most of present day Henan province) in 317 CE. It is stated in the Book of Jin (Jinshu 育書), in the "Biography of Zu Ti":

及京師大亂, 逖率親黨數百家避地淮泗。以所乘車馬載同行老 疾，躬身徒步，藥物衣糧與眾共之，又多權謀，是以少長咸宗 之。(Fang 1974, 1694)

Upon the huge turmoil in the capital, $[\mathrm{Zu}] \mathrm{Ti}$ led several hundred confidante households to seek refuge in Huaisi. [He] used his own carriage to take the elderly and the sick who travelled with him, personally walked [alongside], and shared [his] medicines, clothing, and food with the masses. [ $\mathrm{Zu}$ Ti was] also very tactical, therefore the elderly and the young all made him their clan head.

時帝方拓定江南，未遑北伐，逖進說……帝乃以逖為奮威將軍， 給千人㿋，布三千匹，不給鎧仗，使自招募。仍將本流徙部曲百 余家渡江。(Fang 1974, 1694-95)

At the time, the emperor had just pacified the region south of the [Yangzi] River, with no time to spare for a northward combat. [Zu] Ti presented [his proposal to the emperor] ...The emperor made Ti the General of Might and Power, gave [him] grain for a thousand men and three thousand bolts of cloth. [The emperor] did not provide [Ti with] armour and arms, and made [Ti] conduct self-recruitment. Even so, [Ti] still crossed the [Yangzi] river with his own buqu and other scattered buqu forces, adding up to more than hundreds of households. 
In battle, buqu served as estate armed men; in times of peace, they were treated as similar to dianke 佃客, client farmers. The formation of buqu forces was most active in times when military activities were most frequent. The scale of one's buqu determined one's potential power, easily exceeding thousands. Remarking on the fighting power held by the dominant households of Wu during the Three Kingdoms period (220$280 \mathrm{CE})$, Deng Ai, general of the Wei, reported to his lord on the state of affairs in Wu after Sun Quan had passed away. In the Records of the Three Kingdoms (Sanguozhi 三國志), “Biography of Deng Ai,” (“Deng Ai zhuan” 鄧艾傳) it is said that:

吳名宗大族, 皆有部曲, 阻兵仗勢, 足以建命。(Chen 1959, 777)

The elite lineages and great clans of Wu all have buqu, with fighting forces to rely upon, sufficient for establishing the [heavenly] mandate.

The same was true later in Nanbei chao. In the Book of Chen (Chenshu 陳書), “Biography of Lu Guangda” ("Lu Guangda zhuan” 魯廣達傳) it is said that in the southern state of Chen:

江表將帥, 各領部曲, 動以千數, 而魯氏尤多。(Yao 1972, 418)

The generals and commanders south of the Yangzi River, each led their own buqu [forces], often thousands in number, of which the Lu family had the most.

The nature of a buqu with its own individual allegiance, and as privately-owned by individual households, derived from the fact that the related individuals were mostly privately recruited by, or attached themselves to, estates of land owners and strongmen. Such a practice of hereditary allegiance finds basis in the Three Kingdoms period, when the state of $\mathrm{Wu}$ practiced a hereditary institution for the position of the commanding officers in the military, to enforce the generational subsidiary relationship between the commanding officers and their soldiers (Tao 1933).

The private nature of buqu had strong fiscal impacts. Of the Sixteen Kingdoms (306-439 CE), Li Xiong of Cheng Han stipulated that the buqu of Fan Changsheng's household were not to be taxed by the state. Instead, tax levied from Fan Changsheng's buqu should go into his own household income.

後蜀李雄自稱益州牧, 既克成都, 以山西范長生岩居穴處, 求道養 志，欲迎立為君而臣之，長生固辭。及雄稱櫭成都王，長生自山西 乘素興詣成都。雄迎之於門, 執版延坐, 拜丞相, 尊曰範賢。長生 勸雄稱尊號，雄於是櫭即帝位，加長生為天地大師，封西山侯，複 其部曲, 不豫軍征, 租稅一入其家。(Wang 2006, juan 228, 2559) 
Li Xiong of Later Shu made himself regional governor of Yizhou. Having conquered Chengdu, [Li Xiong] wanted to make Fan Changsheng the new ruler, he who had resided in a mountain cave in Shanxi to practice the way of Dao and to cultivate his resolution. [Li Xiong] himself [would also] submit to Changsheng's rule. Changsheng persistently declined [this offer]. When Xiong usurped for himself the title King of Chengdu, Changsheng arrived in Chengdu from Shanxi in a white carriage. Xiong welcomed him at the gate, held the official tablet in hand and invited him to his seat, made him the prime minister, and respectfully called him Fan the Sage. Changsheng persuaded Xiong to assume the ultimate title, therefore Xiong usurped the emperor's position, and added to Changsheng's title, Master of Heaven and Earth, as well as Duke of West Mountain. Changsheng's buqu forces were resumed, not to be taxed by the military, but all levied tax would go to his own household.

Though in this case the tax exemption benefit enjoyed by Fan Changsheng's buqu was a privilege granted to his household by Li Xiong, in the Wei-Jin Nanbei period, institutions such as "tax-free fields allocated to non-relative clients in a household” (zhantian yinke zhi 占田蔭客制) of the Western Jin or “equal-field system" (juntian zhi均田制) of the Northern Wei all stipulated that the powerful families could retain dependent peasants who were not required to be taxed by the state. As such, these private estates grew larger and wealthier, which gave them more resources to grant protection over their dependents.

Against this socio-historical context, I will now turn to how the practice of maintaining buqu retainers who served as fighting forces of large estates and elite households as early as the Han was most likely picked up by the Tuoba in dealing with the ramifications of the Northern Wei tribal policy. With the disbandment of tribes, the Tuoba wanted to check the power of tribal leaders by severing traditional clan ties while still allowing them to maintain a decent following, one that would be bound by another form of loyalty other than bloodline. Incidentally, the buqu household retainer system was well suited as an answer to the tribal policy. One can even say that the Tuoba had either consciously or subconsciously steered the elite households toward adopting the buqu institution, making it a significant presence in Northern Wei society, so much so that buqu re-emerged as a dominant subject to be applied as a funerary motif in the Pingcheng elite tombs. 


\section{Buqu and the Northern Wei Tribal Policy}

The Northern Wei tribal policy "to disband and to send away the tribes" (lisan buluo 離散部落), was put in motion early on in the dynasty's formative period. It served the purpose of strengthening the hold of the state, at the expense of sovereignty granted to the different pastoral confederations within the Northern Wei realm, consisting of the original tribes who followed the Tuoba in their conquests, surrendered tribes, and conquered tribes. The various pastoral tribes disbanded into a multitude of small groups, as tribal leaders became local officials directly governed by the state and with the responsibilities for fulfilling their conscript and taxation duties. The tribal policy, gradually enforced through each and every Northern Wei military conquest, did not force pastoralists to adopt a settled agricultural lifestyle. Rather, in diminishing the authority of pastoral elites, it provided for the necessary conditions, a prerequisite, to facilitate the Northern Wei social transformation from a tribal confederation into a feudal monarchy. As every social change requires a transition, the appearance of what clearly represents buqu retainers in Pingcheng period tombs demonstrates that the buqu household institution was a convenient alternative for the Tuoba to adopt in the process of executing their tribal policy, exchanging loyalty to blood for loyalty to the master of the household.

This is not to say that the Northern Wei tribal policy directly led to the rising prominence of buqu as a funerary motif in the Pingcheng period, or that when tribal leaders had their native groups disbanded they turned to retaining buqu as an alternative measure. This paper is simply pointing out that social changes may have been a factor in the resurgence of a motif that had a long history in traditional Han funerary repertoire, but had previously not enjoyed a strong presence. Moreover, it is precisely the fact that buqu retainers had been a Han social institution of the large estate households that its appearance as a funerary motif in Han Chinese tombs would have been nothing out of the ordinary, whereas the Tuoba elites would have been viewed as grafting one social institution (buqu) onto the other (tribal ties) to fulfil similar functions.

Much of the social history of everyday life medieval China, namely the Wei-Jin Nanbei period, remains unclear to us. Partly due to social disorder, and partly due to the lack of textual sources characteristic of that period. As a result, without other historical sources to corroborate with the dynastic history, we remain uncertain as to how many of the policies mentioned in passing were actually carried out in reality, including the Northern Wei tribal policy. Only three textual accounts in the Book of Wei mention this social institutional change, though each used a different terminology, which suggests that the tribal policy had taken effect gradually and case by case, rather than executed as one specific mandate. 
凡此四方諸部, 歲時朝貢, 登國初, 太祖散諸部落, 始同為編 民。(Wei 1974, juan 113, 3014)

Any of which of the many tribes from the four directions who paid tribute to court each year, in the beginning of the Dengguo reign, Taizu ${ }^{2}$ disbanded the many tribes, and for the first time treated as registered commoners.

(賀) 訥從太祖平中原, 拜安遠將軍。其後離散諸部, 分土定 居, 不聽遷徙, 其君長大人皆同編戶。訥以元舅, 甚見尊重, 然 無統領。以壽終於家。(Wei 1974,juan 83, 1812)

[He] Ne followed Taizu in pacifying the central plains, [for which] he was made General of Pacifying Afar. Afterwards, the many tribes were disbanded, land allocated for the settlement [of tribesmen], who were not allowed to migrate to other places. The tribal leaders were made into registered commoners. $\mathrm{Ne}$, as the older brother of Taizu's wife, was well respected, but still was without those to lead. He died at an old age in his household.

太祖時, 分散諸部, 唯高車以類粗獷, 不任役使, 故得別為部 落。(Wei 1974, juan 103, 2309)

During the time of Taizu, the many tribes were disbanded. Only the Gaoche tribe, due to its boorish nature, did not allow itself to be commanded [by others], and had to be allowed to exist separately as a tribe.

According to these three Weishu passages, we can say for certain that the tribal policy was initiated in the early days of Tuoba Gui's 拓拔珪 reign, in the formative period of Northern Wei state building, with the earliest account pointing it to the beginning of the Dengguo reign 登國 (386-396). Nonetheless, the vagueness and inconsistency in the language adopted regarding this tribal policy led historians to different interpretations in understanding the actual time of execution of this policy, pushing it till after the Tuoba conquest of Yan 燕 ( 397) (Tang 2000, 196), or even later during the Huangshi reign 皇始 (396-398) of Emperor Daowu 道武帝 (Koga 1991), as well as the scope of disbandment that this policy actually entailed (Tian 1997; Li 1990).

One main issue regarding the tribal policy that has yet to be resolved is how literally one should interpret the accounts in reference to the notion of "disbandment", and if the policy had indeed collapsed the original tribal hierarchy and made all

2 Emperor Daowu, Tuoba Gui, r. 386-409. 
tribal leaders and tribesmen equals as registered commoners of the Northern Wei. Scholars who held the latter view to be true include Tang Changru and Tian Yuqing. In his study of the Helan tribes, Tian leaned towards treating the policy as a complete disbandment of the tribes, that tribal leaders, together with all or parts of their tribes, gave up tribal privileges to become registered commoners (1997). Tang pointed out that "the disbandment of tribes forced elites and commoners to become independent registered households, which, needless to say, facilitated the wiping out of the already diminishing social institution of clanship" $(2000,196)$. Departing from this perspective, it is natural for one to make the logical connection that the disbandment of tribes meant an end to all tribes, and that the continued existence of certain tribal leaders suggested that these particular tribes simply had not yet been disbanded. These scholars had arrived at this conclusion most likely based on their interpretation of the Weishu passage taken from the "Biography of $\mathrm{He} \mathrm{Ne}$," ("He Ne zhuan” 賀訥傳) stating that “Ne, as the older brother of Taizu's wife, was well respected, but still was without those to lead” (Wei 1974, juan 83, 1812).

On the other hand, Yang Enyu's interpretation of a much more "limited" policy in scope appears to be more plausible, especially considering how early on the "disbandment of tribes" was mentioned in Northern Wei state-building, it is hard to believe that the Tuoba would have gone for such a drastic and total change in reducing the power and authority of their fellow tribal confederation leaders (Yang 2006). The main intent behind this policy was to remove the privileges previously enjoyed by the various tribal leaders, denying them the opportunity to rebuild their power base so as to become competing powers against the Tuoba (Tian 2003, 89). Returning to the "Biography of He Ne," before the statement that $\mathrm{Ne}$ "was without those to lead," the same passage also states:

\section{其先世為軍長，四方附國者數十部。(Wei 1974, 1812)}

His ancestors were confederation leaders, who had tens of tribal states from the four directions dependent upon them.

With this in mind, one might interpret the statement that $\mathrm{Ne}$ "was without those to lead" to mean that he was no longer the chief of the confederation, like his ancestors were, and not that he had no tribesmen who followed him and remained at his command. Indeed, following the disbandment of the Helan tribes, it is stated in the Weishu that it was the tribal leaders who were registered into commoners. This suggests that the disbandment policy broke down previously large confederations into much smaller units, whose tribal leaders became registered commoners of the Northern Wei, and the tribesmen who followed them remained at the command of the leader (Mou 2017, 1). Such a policy for disposing of the conquered 
takes precedence from the Zhou's (1046-256 BCE) practice of dividing up the Shang (1600-1046 BCE) clansmen of the Ji surname, using each clan as a single unit, with the original head of the clan still leading this single unit under their own management (He 1982, 2).

Here, one might consider an alternative possibility for the dominance enjoyed by the buqu motif in Pingcheng period tombs, placing a strong emphasis on the presence of the large-scale fighting forces. With the tribal policy in place in the early Pingcheng period, the disbandment of the tribes severed the loyalty between clansmen based on blood ties, and this relationship between masters and their fighting forces was necessarily and ultimately transformed into a new type of loyalty, the household retainer-based system that found its form in buqu. In a way, one can even say that through enforcing the tribal policy, the Tuoba rulers had consciously or subconsciously opted to fall in line with the buqu social establishment, one with deep roots in Chinese society, which conveniently allowed for the social traditions of the Xianbei and those of the Han Chinese to merge together.

Often in the Northern Wei, buqu were treated as a sign of one's ownership, or lack of, political capital. Following their masters in political loyalty, as we can see in the two examples between Northern Wei and the southern state of Song.

昶于彭城奔虜, 部曲皆散, 文和獨送至界上。(Xiao 1972, juan 27, 512) When [Liu] Chang [of the Song] surrendered to the Tuoba in Pengcheng, [his] buqu forces all scattered. Only [the master of records of the Lord Yiyang's expedition to the north, Wang] Wenhe, he alone accompanied [Chang] to the border.

魏荊州刺史魯爽及弟秀等率部曲詣銆歸順。(Wang 2006, juan 217, 2443)

Lu Shuang, provincial governor of Jingzhou under the Wei, together with his brother Xiu and others, led their buqu and submitted themselves [to the Song].

Historians of medieval China have all pointed out that the disbandment of tribes provided the necessary conditions that allowed for the Northern Wei society to transform from pastoralism to a more settled agricultural lifestyle. Breaking up the tribal confederations into smaller units restructured the pastoral clan affiliation into a part of Northern Wei state institution, so that while the tribal leaders lost their hierarchical power in the confederation under the tribal policy, they gained status in becoming part of the Northern Wei administration. Consequently, the 
tribal policy was a step towards feudalisation of the Tuoba Northern Wei, as these new rulers of northern China weaned themselves and their people off the pastoral ways, adapting to the ruling methods of the central plains. As argued by Yang Yaokun, "In the early to mid-Northern Wei, due to the strength of the Xianbei confederation tribal soldiers and the enhanced centralisation of power, it was impossible for the powerful lineages and the great names of the north to organise buqu" (Yang 1991, 129). Nonetheless, it was precisely because the central power of the Northern Wei state wanted to put a check on the strength of the Xianbei confederate tribal leaders that the tribal policy was carried out. In light of such a policy, there was inevitably a need for a conscious, or subconscious, shift in loyalty allegiance from tribal ties to social ties, one that did not challenge the directive of the Northern Wei state. As such, reverting to the traditional Han Chinese social establishment of the buqu, or at the very least, using the buqu concept in reference to such a dependency relationship, seemed to be a more benign recourse.

Indeed, as pointed out by Tang Changru, "The term 'bound retainers' [buqu] appears very seldom in the Northern Wei period, and it is at the end of the dynasty, during the disorders, that such great local lineages as the Gao of Bohai possess bound retainers, but they are used only in warfare" $(1990,130)$. However, it is important to note that historians such as Tang mainly base their studies on the dynastic histories, in which textual accounts of a certain social phenomenon often appear much later in time as it becomes typified and popularised. It is only then that such a social change will appear in the histories. Textual accounts from the Northern Wei remain scarce, and the few that we have regarding the term buqu from this period are either taken from the southern histories or used with relevance to Han Chinese families. The representation of military troops in murals and clay figurines on such a large scale in Pingcheng elite tombs might be the only material evidence that we have to hypothesise on the possible dawn of a changing social reality before it enters into written history. Somewhere in this period of historical silence, the Pingcheng society had either consciously or subconsciously chosen the buqu institution as the more fitting alternative to fill in the social power void left behind by the tribal policy.

With a long history as a social institution since the Han, buqu was not an alien concept, at least to the Han Chinese. It is thus not unlikely, maybe even logical, that the Tuoba would have looked to the traditional buqu institution as the new social establishment to deal with the ramifications of the tribal policy. Using the notion of buqu to replace the original tribal ties, even though most of the followers of these recently registered tribal leaders would have still been their clansmen to begin with, their loyalty to their master was no longer necessarily bound by blood or kin, but by the confines of an existing social institution. Of course, whether or 
not a refugee/migrant imperial family (Huang 2017) such as the likes of Sima Chuzhi and Sima Jinlong who defected to the North, would have been permitted to have buqu retainers on their estates within the vicinity of the Pingcheng capital is a subject that deserves the discussion of a paper by itself. In fact, Northern Wei regulations on retaining armed men for elite households residing within the capital is a specialised subject that would require further detailed examination of the textual histories.

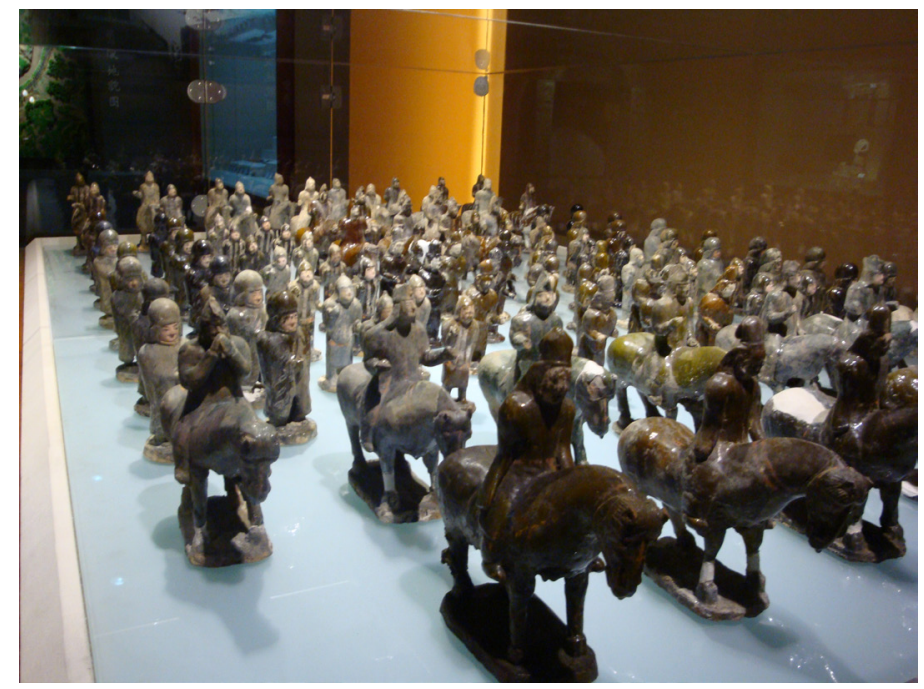

Figure 3: Clay figurine set in the tomb of Sima Jinlong, Shanxi (author's photo taken at the Datong Museum).

While nothing exists in historical documents to indicate the actual status of buqu in Northern Wei, it is interesting to note that the first time buqu was written into textual history as a legal social status was in the Northern Zhou (557-581 CE), which must have carried on much of the social practices of the Northern Wei. In the eleventh month of the sixth year of the Jiande reign 建德 (577) under Emperor Wudi 武帝, after the Zhou conquest of Qi, a decree was issued for the release of Qi captives who were originally of liangren 良人 (literally “virtuous people," commoner) social status and taken in as slaves, together with the Liang captives from the Western Wei conquest of 534, who were now all living in the realm of the Zhou.

及平江陵之後, 良人沒為奴婢者, 並宜放免。所在附籍, 一同民 伍。若舊主人猶須共居, 聽留為部曲及客女。(Linghu 1971, juan $6,104)$ 
[...] as well as after having conquered Jiangling [in the year 534], the good population who had been taken in [and demoted to] slaves, are all to be released. They are to be entered into local household registration, to be treated in the ranks of the commoners. If their former masters still require them to reside within the same household, they will obey and remain as buqu and kenü.

Tang Changru sees the issuing of this decree in 577 as a watershed event that marked the legitimisation of buqu by law. Before this, though personal dependencies in a feudal society had developed into somewhat of a retainer system, the type of dependent relationship was often unstable and without legal recognition (Tang 1983, 18). With this decree, it is clear to us that by the Northern Zhou it was well established that buqu retainers were different from slaves (nubi 奴婢), yet still below the class of liangren, classified as jiankou 賤口 (literally "unworthy population"; inferiors).

This decree paved the way for the legal stipulation of buqu in the seventh century Tang Codes (Tanglü 唐律), of which the definition of buqu had clearly taken after the legacy of the Northern Zhou decree. Though privately-owned by masters, just like slaves, unlike the latter buqu were not given a price when transferring between the hands of different masters, which clearly indicates that buqu were not considered to be the private "property" of the master that could be bought or sold (Zhangsun 1983, juan 25, 468).

諸謀反及大逆者皆斬……若部曲資財田宅，並沒官。疏議曰：部 曲不同資財，故特言之……奴婢同資財，故不別言。(Zhangsun 1983, juan 17, 321-22)

Those who have attempted rebellion and treason should all be executed ... buqu, property, and estate etc. should be confiscated by the state. Shuyi commentary states: Buqu are different from property, thus they are separately listed ... Slaves are the same as property, and thus they are not separately listed.

部曲者, 謂本是賤品, 賜姓從良而未離本主。本主身死……(部 曲）衣資畜產，隨身所屬，不合追奪。(Shi 1895, T45, no. 1895)

$B u q u$, was originally of the inferior class, who were granted surnames and turned into commoners but never left their original masters. When the master dies ... clothing, property, livestock, and estate [that belonged to buqu] are their personal property. To have these taken from them would be inappropriate. 
Moreover, apart from not being the personal property of any master in the Tang Dynasty, the above accounts clearly stipulate that while buqu belonged to their household masters, they could possess their own personal property, including estate and livestock. This is an important point of information if we take into account that the Tang Codes were compiled based on legal codes adopted after social practices that were put into legal terms in the Northern Dynasties.

\section{Conclusion}

There is no doubt that buqu were already a well-recognized funerary visual motif on the Han pictorial stones and the Wei-Jin brick murals (Wang 2017, 97), one which continued into the Northern and Southern Dynasties, with recognised examples on the pictorial bricks in Dengxian, Henan province (Ma 2016). While these representations all remain as a pictorial depiction in mural painting or moulded pictorial bricks, with the Pingcheng examples we see a distinct development of this motif in scale (into one of the central motifs that takes up an entire wall space) and in the type of representation medium (into a set of clay figurines) by the Northern Wei. Changes in material culture usually suggest the possibility of social change, and the prominent representation of these military troops in Pingcheng period tombs might reflect a resurgence of buqu retainers at a time when the Northern Wei tribal policy was being implemented piecemeal. This social reality could have made a stronger impact in funerary repertoire before being registered in textual accounts. So much so that instead of remaining as a mural image, for re-enacting the daily life of the tomb occupant, these clay figurines came to represent the retainers who remained dependents of the master's household, and who would remain loyal to the master into eternity.

\section{References}

Chen, Shou 陳壽. 1959. Sanguozhi 三國志 (Records of the Three Kingdoms), 65 juan, $280 \mathrm{CE}$. Beijing: Zhonghua shuju.

Datong shi kaogu yanjiusuo 大同市考古研究所. 2006. “Shanxi Datong Shaling Bei Wei bihuamu fajue jianbao 山西大同沙嶺北魏壁畫墓發掘簡報 (Excavation Report on the Shanxi Datong Shaling Northern Wei Mural Tomb).” Wenwu 文物 10: 4-24.

—.2008. Datong Yanbei shiyuan Bei Wei muqun大同雁北師院北魏墓群 (Datong Yanbei Shiyuan Northern Wei Tomb Cluster), edited by Liu Junxi 劉俊喜. Beijing: Wenwu chubanshe. 
Fan, Ye 范曄 et al. 1965. Hou Hanshu 後漢書 (Book of Later Han), 120 juan, 445 CE. Beijing: Zhonghua shuju.

Fang, Xuanling 房玄齡 et al. 1974. Jinshu 晉書 (Book of Jin), 132 juan, 648 CE. Beijing: Zhonghua shuju.

Graff, David. 2009. Medieval Chinese Warfares, 300-900. London: Routledge. He, Ziquan 何茲全. 1982. Dushiji 讀史集 (Collection on Reading History). Shanghai: Renmin chubanshe.

Huang, Wenyi. 2017. "Negotiating Borders: Cross-border Migrants in Early Medieval China.” PhD Diss., McGill University.

Ke, Yougen 柯友根. 1963. “Xi Han buqu chutan 西漢部曲初探 (Preliminary Exploration into Western Han buqu).” Xiamen daxue xuebao 廈門大學學報 2: 24-34.

Koga, Akimine 古賀昭岑. 1991. “Lun Bei Wei buzu de jiesan 論北魏部族的 解散 (On the Disbandment of Northern Wei Tribes).” Translated by Liu Shizhe 劉世哲. Minzu yicong 民族譯叢 5: 36-44.

Lewis, Mark. 2009. China Between Empires: The Northern and Southern Dynasties. Cambridge, MA: Harvard University Press.

Li, Ping 李憑. 1990. “Bei Wei lisan zhubu wenti kaoshi 北魏離散諸部問題考實 (Investigation into the Northern Wei Tribal Policy Issue).” Lishi yanjiu 歷史 研究 2: 42-52.

Linghu, Defen 令狐德葉 et al. 1971. Zhoushu 周書 (Book of Zhou), 50 juan, 636 CE. Beijing: Zhonghua shuju.

Liu, Bin 劉斌. 2014. “Luoyang Beimangshan Bei Wei damu kaogu ji 洛陽北邡山 北魏大墓考古記 (Archaeological Notes on the Northern Wei Grand Tomb at Luoyang Beimang Mountain).” Dazhong kaogu 大眾考古 5: 32-38.

Ma, Jidong 馬繼東. 2016. "Yi Dengxian huaxiangzhuan kan Nanchao renwuhua shenmei fengshang 以鄧縣畫像磚看南朝人物畫審美風尚 (A Study on the Aesthetics in Figural Painting of the Southern Dynasties through the Dengxian Pictorial Bricks).” Meishu daguan 美術大觀 10: 92.

Mou, Fasong 牟發松. 2017. “Bei Wei jiesan buluo zhengce yu lingmin qiuzhangzhi zhi yuanyuan xintan 北魏解散部落政策與領民酋長制之淵源新探 (A New Investigation into Northern Wei Tribal Policy and the Origination of the Leading Chieftain Establishment)." Huadong shifan daxue xuebao (Zhexue shebui kexue ban) 華東師範大學學報（哲學社會科學版） 5: 1-12.

Panofsky, Erwin. 1964. Tomb Sculptures. New York: Harry N. Abrams, Inc.

Shanxi sheng Datong shi bowuguan 山西省大同市博物館 and Shanxi sheng wenwu gongzuo weiyuanhui 山西省文物工作委員會. 1972. “Shanxi Datong Shijiazhai Bei Wei Sima Jinlong mu 山西大同石家寨北魏司馬金 龍墓 (Northern Wei Tomb of Sima Jinlong in Shijiazhai, Datong, Shanxi Provence)." Wenwu 文物 3: 20-33, 64. 
Shi, Daoxuan 釋道宣. 1895. “Liangchu qingzhongyi 量處輕重儀 (Standards for Calculating and Dealing with the Light and Heavy [Possessions])." Collected in the Taisho Tripitaka 大正新修大藏經 45.

Shi, Guangming 施光明. 1991. “Xizhou da xing Dunhuang Song shi yanjiu 西 州大姓敦煌宋氏研究 (A Study on the Song Clan, a Prominent Clan of Xizhou).” In Wei Jin Nanbei chao shilun wenji 魏晉南北朝史論文集 (Essays on Historical Discussions of the Wei-Jin Nanbei Period), edited by Shanghai Museum, 166-77. Jinan: Qilu shushe.

Tang, Changru 唐長孺. 1983. “Wei Jin Nanbeichao shiqi de ke he buqu 魏 晉南北朝時期的客和部曲 (Clients and Buqu in the Wei-Jin Nanbeichao Period)." In Wei Jin Nanbei chao shilun shiyi 魏晉南北朝史論拾遺 (Further Studies on the Wei-Jin Nanbei chao Historical Discussions), 1-24. Beijing: Zhonghua shuju.

-. 1990. "Clients and Bound retainers in the Six Dynasties Period." In State and Society in Early Medieval China, edited by Albert E Dien, 111-38. Stanford: Stanford University Press.

—. 2000. Wei Jin Nanbei chao shi luncong 魏晉南北朝史論叢 (Wei-Jin Nanbei chao Historical Studies). Shijiazhuang: Hebei jiaoyu chubanshe.

Tao, Chunhui 陶春慧. 2013. “Bei Wei Pingcheng muzang huihua jianshu 北魏平 城墓葬繪畫簡述 (Overview of Northern Wei Pingcheng Tomb Paintings).” Wenwu shijie 文物世界 2: 48-51.

Tao, Yuanzhen 陶元珍. 1933. “Sanguo Wubing kao 三國吳兵考 (Examination of the Wu Soldiers in the Three Kingdoms).”Yanjing xuebao 燕京學報 13: 49-88.

Tian, Yuqing 田余慶. 1997. “Helan buluo lisan wenti-Bei Wei lisan buluo ge’an kaocha zhiyi 賀蘭部落離散問題——北魏“離散部落”個案考察之一 (The Issue on Disbanding the Helan Tribe: A Case Study on the Northern Wei Tribal Policy)." Lishi yanjiu 歷史研究 2: 31-39.

—. 2003. Tuoba shitan 拓跋史探 (An Investigation into the Tuoba History). Beijing: Sanlian shudian.

Wang, Jiangpeng 王江鵬. 2017. "Wei-Jin Nanbei chao muzang bihua renwu tuxiang de peizhi fangshi fenxi 魏晉南北朝墓葬壁畫人物圖像的配置方式分 析 (Analysis of the Compositional Distribution of Figural Murals in Wei-Jin Nanbei chao tombs).” Meishu yu sheji 美術與設計 6: 97.

Wang, Qinruo 王欽若, Yang Yi 楊億, Sun Shi 孫媔 et al. 2006. Cefu yuangui 冊 府元龜 (Prime Tortoise of the Record Bureau), 1000 juan, 1005 CE. Nanjing: Fenghuang chubanshe.

Wei, Shou 魏收. 1974. Weishu 魏書 (Book of Wei), 114 juan, 554 CE. Beijing: Zhonghua shuju.

Wang, Wanying 王萬盈. 2004. “Lun Wei Jin Nanbei chao shiqi de buqu jiqi yanjin 論魏晉南北朝時期的部曲及其演進 (On Buqu and its Development in 
the Wei-Jin Nanbei chao).” Xibei shida xuebao (Shebui kexue ban) 西北師大學 報（社會科學版） 4: 41-46.

Wei, Zheng 韋正. 2017. “Datong Bei Wei muzang bihua yanjiu 大同北魏墓葬 壁畫研究 (A Study of Datong Northern Wei Tomb Murals).” In Bishang guan—Xidu Shanxi gudai bibua 壁上觀——細讀山西古代壁畫（Close Reading of Shanxi Ancient Murals), edited by Shanghai Museum, 96-111. Beijing: Peking University Press.

Yang, Enyu 杨恩玉. 2006. “Bei Wei lisan buluo yu shehui zhuanxing- — jiu lisan de shijian, neihan ji mudi yu Tang Changru, Zhou Yiliang, Tian Yuqing zhu mingjia shangque 北魏离散部落与社会转型——就离散的时间、内涵及 目的与唐长孺、周一良、田余庆诸名家商榷 (Northern Wei Tribal Policy and Social Transformation: A Deliberation on the Time, Meaning and Intent of the Disbandment of Tribes with Renowned Scholars Including Tang Changru, Zhou Yiliang, and Tian Yuqing).” Wen shi zhi 文史哲 6: 105-10.

Yang, Yaokun 楊耀坤. 1986. “Dong Wei Bei Qi bingzhi gailun 東魏北齊兵制 概論 (Overview of Eastern Wei and Northern Qi Military Institutions).” Zhongguo Wei-Jin Nanbei chao shi xuehui di er jie xueshu taolunhui lunwenji 中 國魏晉南北朝史學會第二屆學術討論會論文集 (Essay Volume for the Second Symposium of China Wei-Jin Nanbei chao Historical Association), 119-35. Jinan: Qilu shushe.

Yao, Silian 姚思廉. 1972. Chen shu 陳書 (Book of Chen), 36 juan, 636 CE. Beijing: Zhonghua shuju.

Zhangsun, Wuji 長孫無忌 et al. 1983. Tanglü shuyi 唐律疏議 (Tang Code with Commentary), 30 juan, 653 CE. Beijing: Zhonghua shuju.

Zhang, Qingjie 張慶捷. 2017. "Xiangei lingyige shijie de huazuo-Bei Wei Pingcheng muzang bihua 獻給另一個世界的畫作一一北魏平城墓葬壁畫 (Painting Dedicated to the Other World).” In Bishang guan—Xidu Shanxi gudai bihua 壁上觀——細讀山西古代壁畫 (Close Reading of Shanxi Ancient Murals), edited by Shanghai Museum, 82-95. Beijing: Peking University Press.

Zhongguo shehui kexueyuan kaogu yanjiusuo Luoyang Han Wei chengdui 中國 社會科學院考古研究所洛陽漢魏城隊 and Luoyang gumu bowuguan 洛陽 古墓博物館. 1994. “Bei Wei Xuanwudi Jingling fajue baogao 北魏宣武帝景 陵發掘報告 (Excavation Report of Northern Wei Emperor Xuanwu's Jing Mausoleum).” Kaogu 考古 9: 801-14.

Xiao, Zixian 蕭子顯. 1972. Nan Qi shu 南齊書 (Book of Southern Qi), 59 juan, 509-519 CE. Beijing: Zhonghua shuju. 